\title{
SOCIALINIŲ PASLAUGŲ BENAMIAMS İGYVENDINIMAS LIETUVOJE: BENAMIŲ VYRŲ PATIRTYS
}

\author{
Violeta Ivanauskienė, Natalja Gončiarova \\ Vytauto Didžiojo universitetas, Kauno technologijos universiteto \\ Inžinerijos licèjus
}

\begin{abstract}
Anotacija
Šiandieninèje Europoje niekas negali būti verčiamas miegoti gatvèje vien tik dèl to, kad nèra pritaikytų tinkamos kokybės paslaugų, kurios atitiktų žmogaus poreikius. Todėl, atsižvelgdama ị tai, valstybė privalo užtikrinti benamystę išgyvenančių asmenų teises ir išsaugoti jų orumą, teikdama efektyvias ir kokybiškas socialines paslaugas, nes tokių paslaugų reguliavimas ir igyvendinimas benamystės srityje leidžia kalbėti apie modernios valstybės vystymą, formuojant ir performuojant socialinių paslaugų teikimo modelį. Šiame straipsnyje, remiantis benamystę išgyvenančių vyrų patirtimis, aptariamos pagrindinès socialinių paslaugų problemos ir jų plètros galimybès. Straipsnyje pristatomas empirinis tyrimas, kurio rezultatai atskleidè, kad šalyje socialinès apsaugos sistema paremta materialiniu aprūpinimu, tad benamių vyrų galimybės gauti kokybišką paslaugą yra menkos. Judejimo negalią turinčiam žmogui nakvynès namų infrastruktūra nepritaikyta; socialinis būstas dèl ilgų eilių sunkiai gaunamas; savarankiško gyvenimo ar senelių globos namai garbaus amžiaus benamiams taip pat sunkiai prieinami.

PAGRINDINIAI ŽODŽIAI: benamiai vyrai, socialinės paslaugos, ịgyvendinimas.
\end{abstract}

\begin{abstract}
This article analyses the experiences of men who are suffering homelessness. The aim of this article is to identify the main problems of social services and to show their potential development. In today's Europe, no one can be forced to sleep on the street just because there are no high-quality services that meet human needs. The state must ensure the rights of persons, who are suffering homelessness and to preserve their dignity by providing efficient and high quality social services, because only this kind of services allows to talk about the development of the modern state, shaping and reshaping the model of social services. This research allows to understand the phenomenon of homelessness from the point of view of homeless men and to identify the main problems that hinder to overcome homelessness. This article presents the empirical study, which results showed that social services in Lithuania are based on the material supply, so homeless men have poor access to quality social services. The infrastructure of hostels is not adapted for person with disability; social housing is difficult to obtain because of the long queues; homeless men also have difficulties to access independent living or nursing homes for the elderly.

KEY WORDS: homeless men, social services, the implementation.
\end{abstract}

DOI: http://dx.doi.org/10.15181/tbb.v76i1.1513

\section{Ivadas}

Benamių, elgetų būta visais laikais. Benamystès problematika yra tarpdisciplininis pažinimo objektas, kurio negalima ịsprausti vien tik ị sociologijos, kriminologijos ar etnologijos rėmus (Praspaliauskienė, 2000). Kritiniu požiūriu benamys- 
té - tai individualių ir struktūrinių veiksnių pasekmè. Benamystę gali lemti asmeniniai sutrikimai, priklausomybės ligos ar prastos gyvenimo sąlygos, susijusios ir su plataus spektro sisteminiais veiksniais, tokiais kaip būsto neprieinamumas ir nepakankamos įdarbinimo galimybès (Kuhn, Culhane, 1998, cit. Cronley, 2010). Benamiai žmonès susiduria su socialinių, ekonominių išteklių stoka. Atsižvelgdama ị tai, valstybė privalo užtikrinti benamystę išgyvenančių asmenų teises ir išsaugoti jų orumą. Socialinių paslaugų reguliavimas ir įgyvendinimas benamystès srityje leidžia kalbèti apie modernios valstybès vystymą, formuojant ir performuojant socialinių paslaugų teikimo modelị. J. Veit-Wilson (2000) (cit. Dromantiené, 2004) analizavo gerovés valstybès sąvokos problemiškumą, kad jos esmè - valstybès gebejjimas mažinti skurdą, socialinę atskirti, ginti žmogaus teises. Tuo tarpu G. Esping-Andersenas (1990, cit. Dromantienè, 2004) teigè, kad gerovès valstybė siejama su valstybės atsakomybe už tam tikros minimalios gerovès užtikrinimą savo piliečiams. Siekiant panaikinti skurdą, socialinę atskirtí, užtikrinti asmenų lygiateisiškumą gerovès valstybèje, svarbu tyrinèti valstybès socialinių paslaugų reguliavimą ir igyvendinimą, remiantis ne tik moksline literatūra, bet ir pačių vartotojų patirtimis. Todẻl šio straipsnio tikslas, remiantis benamystę išgyvenančių vyrų patirtimis, identifikuoti pagrindines socialinių paslaugų problemas, apibūdinant ir jų plètros galimybes. Tyrimo objektas - benamystei skirtų socialinių paslaugų igyvendinimas Lietuvoje. Straipsnio tikslą siekiama igyvendinti analizuojant ne tik mokslinę literatūrą, bet ir remiantis atlikto empirinio tyrimo duomenimis.

Tyrimo metodas. Analizuojant benamystei skirtu socialinių paslaugu igyvendinimą Lietuvoje, benamių vyrų požiūriu, atliktas kokybinis tyrimas. Atlikti 9 iš dalies struktūruoti kokybiniai interviu su nakvynès namuose gyvenančiais vyrais. Interviu vidutinè trukmè - 55 minutès. Tyrimo dalyviai atrinkti pagal „sniego gniūžtès" principą, kai pirmuosius tyrimo dalyvius rekomendavo nakvynès namų darbuotojai, o kiti pakviesti dalyvauti tyrime, atsižvelgiant ị pirmujų nuorodas ar rekomendacijas. Tyrimas atliktas laikantis visų moksliniams tyrimams keliamų etinių reikalavimų: konfidencialumo, anonimiškumo, objektyvumo, laisvanoriškumo. Atliekant tyrimą surinkti duomenys pateikiami autentiška tyrimo dalyvių kalba.

\section{Benamystei skirtų socialinių paslaugų reguliavimas ir ịgyvendinimas}

Lietuvoje benamystès problemoms spręsti parengtos kelios strategijos: Socialinès įtraukties didinimo 2014-2020 m. veiksmų planas (2014), kuriuo siekiama didinti gyventojų gerovę, mažinant skurdą bei užtikrinant visiems lygias galimybes; Skurdo mažinimo Lietuvoje strategija (2000), kurioje išskiriama 10 svarbiausių 
viešosios politikos sričių, galinčių numatyti sprendimus, palengvinančius skurstančiųu padètị, pabrěžiant NVO ir socialinių partnerių svarbą, LR bendrasis aprèpties memorandumas (JIP) (2003), kuriuo siekiama parengti Lietuvą nuo pat jos ịstojimo ị ES dalyvauti socialinès aprèpties procese, taikant atvirojo koordinavimo metodą. Memorandumas nusako pagrindinius iššūkius, siekiant įveikti skurdą ir socialinę atskirtị, supažindina su pagrindinėmis šių problemų sprendimo politikos priemonèmis.

Be šių strategijų, ankstesniais metais buvo priimtas ir igyvendinamas 2004$2006 \mathrm{~m}$. nacionalinis kovos su skurdu ir socialine atskirtimi veiksmų planas (NAP), Lietuvos socialinès apsaugos ir socialinès aprèpties strategija 20082010 m. (NP - SASAS). Nors šios strategijos priimtos, tačiau daugelis išsikeltų tikslų neiggyvendinti. Benamystès mastai šalyje ir toliau didèja, skurstančiųjų daugèja, o socialinès paramos skirstymo sistema išlieka neefektyvi. Lietuvai ịstojus i ES, politiniu lygmeniu atsirado daugiau strategijų, dèmesys pradètas kreipti ị skurdo problemą, integruojant benamius ị ịvairius visuomeninius renginius, tačiau nepaisant to ir toliau svarbu dirbti šioje srityje ir vietos, ir nacionaliniu, ir tarptautiniu lygmenimis. ES strategijoje $2020^{1}$ iškeltas tikslas, kuriuo siekiama iš skurdo išlaisvinti 20 milijonų žmonių. Toks tikslas turètų būti ir Lietuvos strateginiuose planuose, siekiant kuo labiau mažinti Lietuvos benamių asmenų skaičių, plètojant socialines paslaugas.

Europoje 1989 m. ịkurta „Feantsa“ organizacija / federacija, skirta kovai su skurdu ir socialine atskirtimi, padedant žmonėms, kurie išgyvena benamystę, arba tiems, kuriems ji gresia. Šiuo metu „Feantsa“ turi daugiau kaip 100 narių trisdešimtyje Europos valstybių, įtraukiant ir 25 ES šalis. Tai vienintelè tinklinè organizacija Europoje, dirbanti su benamystes problema. 2010 metai buvo paskelbti benamystės metais, ta proga pradèta reklaminė kompanija su šūkiu: „Panaikinti benamystę - įmanoma“ (angl. Ending homlessness is possible!). Šia kompanija siekta atkreipti dèmesị ị tai, kad benamystę lemia ne tik asmeninès problemos, bet ir struktūriniai, instituciniai veiksniai (prastas paslaugų koordinavimas, neadekvatus pašalpų sistemų struktūravimas, nepakankamos politikos kūrejjų ir jos ịgyvendintojų pastangos), todèl labai svarbu investuoti laiką ir išteklius ị ilgalaikius šios problemos sprendimus (,Feantsa“. Panaikinti benamystę yra įmanoma!).

Tuo tarpu Lietuvoje, igyvendinant socialines paslaugas benamystę išgyvenantiems asmenims, veikia 23 nakvynès namai, kuriuose teikiamos laikino apnakvindinimo arba laikino apgyvendinimo paslaugos žmonèms, praradusiems namus. Šalia šių paslaugų, nakvynès namų gyventojams teikiamos ir kitos kompleksinės socialinės paslaugos. Remiantis socialinių paslaugų ịstatymo (2006) antrojo skirsnio 7 ir 8 str., benamystę išgyvenantys žmonès gali gauti bendrąsias (informa-

1 Prieiga internete: http://www.feantsa.org/spip.php?article411\&lang=en 
vimas, konsultavimas, tarpininkavimas, atstovavimas, sociokultūrinès paslaugos, transporto organizavimas, maitinimo organizavimas, aprūpinimas būtiniausiais drabužiais ir avalyne) ir specialiąsias (socialinè priežiūra, laikinas apnakvindinimas, socialinių igūdžių ugdymas ir palaikymas) socialines paslaugas. Atsižvelgiant ị tai, dažnai manoma, kad suteikus laikiną prieglobstį benamystès problema išsispręs, tačiau taip nèra. Svarbu orientuotis ị priežastis, kurios lèmė benamystę, ir operatyviai jas spręsti. Be to, praktinè patirtis atskleidžia, kad neretais atvejais asmenys, apgyvendinti nakvynès namuose, išèję iš jų grį̌ta ị gatvę. Likus gatvejje iš tiesų sunku atsiriboti nuo žmogų supančios aplinkos, ypač nuo gatvejje sutiktų draugų, kolegų (Vilniaus miesto socialinès paramos centro $2014 \mathrm{~m}$. veiklos ataskaita, 2015).

Šalia minètų paslaugų, benamystę išgyvenantiems žmonẻms sudaromos sąlygos naudotis ir dienos centro paslaugomis, kur jie gali ne tik praleisti pusiaudieni, bet ir pasigaminti, pasišildyti maistą, gauti socialinio darbuotojo konsultacijas ir dalyvauti organizuojamuose grupiniuose užsièmimuose. Dienos centre besilankantys asmenys skatinami laikytis tam tikrų taisyklių, tvarkos, atlikti smulkų remontą (Socialinès rizikos asmenų, neturinčių nuolatinės gyvenamosios vietos ir elgetaujančių, 2013-2018 metų integracijos ir socialinès pagalbos programa, 2013). Iš esmès dienos centrai atlieka ne tik tam tikro „prieglobsčio“ funkciją, kur benamystę išgyvenantys žmonès gali praleisti šaltas žiemos, rudens ar pavasario dienas, bet ir ugdytis kasdienius gyvenimo ịgūdžius, gauti reikalingą socialinio darbuotojo pagalbą. Galima teigti, kad įsteigti dienos centrai ir teikiamos paslaugos padeda benamiams asmenims išvengti sudètingesnių sveikatos problemų, nusikalstamos veiklos, psichotropinių medžiagų vartojimo, laiką leidžiant ne tik gatvėse, bet ir šiuose centruose.

Tuo tarpu senyvo amžiaus ar negalią turintiems benamiams teikiamos ir savarankiško gyvenimo namuose paslaugos. Apgyvendinimas šiuose namuose - tai namų aplinkos ir būtinų socialinių paslaugų teikimas asmenims ir šeimoms, kuriems nereikia nuolatinès ar intensyvios priežiūros, kartu sudarant sąlygas jiems savarankiškai tvarkytis savo asmeninį / šeimos gyvenimą. Senyvo amžiaus žmonès gali naudotis šia paslauga, jei neturi nuosavybės teise jiems priklausančio gyvenamojo būsto ir kuriems paslaugos negali būti teikiamos namuose. Išskirtiniais atvejais savarankiško gyvenimo paslauga gali būti teikiama ir asmenims, atsidūrusiems ekstremalioje socialinèje padètyje (Vilniaus miesto socialinès paramos centras). Galima daryti prielaidą, kad ekstremali socialinè padètis gali būti tada, kai, pavyzdžiui, rajonuose nėra nakvynès namų, kuriuose galètų būti apgyvendinami benamiai asmenys.

Šalia savarankiško gyvenimo namų, dienos centro ir kitų teikiamų paslaugų svarbu kalbėti ir analizuoti vieną pagrindinių piliečio teisių, kurią valstybẻ pri- 
valo užtikrinti, - tai teisè ị būstą. Remiantis Europos socialinès chartijos (2001) 31 straipsniu, LR valstybè ịsipareigoja imtis priemonių, kurios būtų orientuotos i galimybes kiekvienam piliečiui turèti atitinkamo standarto būstą; neleisti plisti benamystei ir ją mažinti, suteikiant galimybę asmeniui ịgyti būstą ar padaryti ji prieinamą tiems, kurie neturi pakankamai lèšų. Remiantis Lietuvos Respublikos paramos būstui ịsigyti ir išsinuomoti ịstatymo (2014) trečio skirsnio 9 straipsniu, valstybè teikia paramą būstui įsigyti tiems asmenims ir šeimoms, kurie deklaravo turimą turtą ir jų gautos pajamos už kalendorinius metus mažesnès už pajamas ir turtą, kuriuos nustato Vyriausybè, ir kurie neturi bei neturèjo būsto nuosavybès teise arba turi / turèjo nuosavybės teise būstą, bet jo plotas mažesnis negu 14 kvadratinių metrų ir jis nusidèvejęs daugiau kaip 60 procentų, ar turimas būstas nepritaikytas neịgaliụjų poreikiams. Taigi benamystès reiškinys politiniu lygmeniu neatsiejamas nuo socialinio būsto politikos: LR valstybė privalo užtikrinti individo teisę ị būstą, kaip pagrindinę socialinę teisę, užtikrinančią žmogaus orumą.

Remiantis Lietuvos Respublikos statistikos departamento duomenimis (2013), 2013 m. buvo 32542 asmenys (šeimos), turintys teisę ị socialinị būstą ir įtraukti i savivaldybėse sudaromus sąrašus. Tuo tarpu $2012 \mathrm{~m}$. šis skaičius buvo 31584 asmenys, o $2011 \mathrm{~m} .4$ proc. mažiau negu $2012 \mathrm{~m}$. Akivaizdu, kad socialinio būsto poreikis kiekvienais metais didejja. Teikdama socialinio būsto paramą, valstybė orientuojasi ị vidinị apsirūpinimo lygị šalyje, tačiau galų gale pati valstybė tampa nebepajegi suteikti paramą visiems turintiesiems ị ją teisę: per metus patenkinama tik apie 1 tūkst. prašymų suteikti socialinį būstą. Remiantis statistiniais duomenimis, socialinio būsto poreikis šalyje smarkiai auga, eilèse žmonès priversti laukti 10 ir daugiau metų. Benamystę išgyvenantiems asmenims socialinio būsto prieinamumas ypač svarbus. Šie žmonès negali eilèse laukti 15 metų, neturẻdami kur gyventi. Jiems socialinė pagalba ir jos prieinamumas būtini „čia ir dabar“. Tol, kol nebus ilgalaikių socialinių paslaugų arba jos netaps labiau prieinamos, žmonių, gyvenančiu gatvėse, skaičius nemažès.

Apibendrinant galima teigti, kad benamystę išgyvenantys žmonès gali gauti tam tikras socialines paslaugas: nuo socialinių paslaugu ịstaigose iki socialinio būsto ịgijimo. Analizuojant šias paslaugas galima pastebėti, kad jos yra trumpalaikès, nors ir orientuotos ị socialinès atskirties ịveiką. Nesant ilgalaikès pagalbos, benamystę išgyvenantys žmonès, pasinaudoję jiems skirtomis paslaugomis, vèl atsiduria gatvejje ir stengiasi išgyventi vartodami psichotropines medžiagas, atlikdami nusikalstamas veikas ir kt. Socialinio būsto teikimas siejamas su solidarumo principu, kuris išryškina valstybės teikiamos pagalbos svarbą vargingiau gyvenančiai visuomenès daliai, nepaisant to, skurstančiųų ir benamystę išgyvenančių žmonių skaičius auga, socialinès paslaugos (ribotas nakvynès namų ir lovų skaičius) ir socialinis būstas vis sunkiau prieinami. Todèl ir toliau svarbu tyrinèti, 
analizuoti bei tobulinti socialinès paramos skyrimą skurdžiausiai gyvenantiems valstybès žmonėms, benamiams.

\section{Benamiai vyrai ir socialinės paslaugos: tyrimo rezultatai}

Benamystę išgyvenantys asmenys turi daugybę rimtų socialinių ir sveikatos problemų, kurios susijusios su priklausomybių ligomis ar psichikos sveikata, todèl šiai grupei žmonių ypač svarbios socialinès paslaugos (Tainio, Fredriksson, 2009). Jų prieinamumą, probleminius aspektus geriausiai gali atskleisti benamiai žmonės, kalbedami apie savo poreikius ir paslaugų atitikimą jiems. Roberto teigimu, jo pagrindiniai poreikiai esamoje situacijoje susiję su sveikatos stiprinimu:

Man poreikiai dabar ką, susitvarkyti su ta koja, vat, reikia, kad tą sąnarị pakeistų <..> pakeis tą sąnari paskui ieškosiu, kur išsinuomoti butą... Čia pusantrų metų, daugiau nelaiko, bendrai taip paemus. Čia tai irgi nesąmonè $<\ldots>$ tai va, tokia ta ir viltis: išsigydyti koją pirmiausia man... ir išsinuomoti butą. Išsinuomoti butą, o po to aš žinau, ką daryti... ką daryti... man draugai padès, tikrai žinau, kas man padès, iš tikrųjų [Robertas, 57].

Iš pateiktos istorijos galima pastebėti, kad kalbėdamas apie savo poreikius tyrimo dalyvis jų neatsieja nuo socialinių paslaugų. Jis žino, kad pagerèjusi sveikata ir galimybė judèti turès lemiamos įtakos jam išeinant iš nakvynès namų ir susirandant gyvenamają vietą. Idomu pastebėti, kad kalbėdamas apie ateitị tyrimo dalyvis ją sieja su draugų, o ne su valstybès pagalba (,man draugai padès, tikrai žinau“). Galima daryti prielaidą, kad toki Roberto pasirinkimą lemia aiškaus ir apibrèžto socialinio gerovès modelio Lietuvoje nebuvimas. Viena vertus, dominuoja socialdemokratinis modelis, kita vertus, atsižvelgiant ị igyvendinamą politiką, Lietuvai artimas ir liberalusis modelis. Tol, kol valstybės sistema išlieka mišri, nèra pusiausvyros, tol žmogus šioje situacijoje lieka nuošalyje, jam nesuteikiama būtina pagalba. Tai patvirtina gaunamos socialinès paslaugos ir darbo rinka, kuri netenkina benamių žmonių poreikių:

Čia vasara nedirba, uždaro 3 mėnesiams ar keturiems... gyvenk, kur nori, kur tada miegoti? < ..> dabar, va, po pusantrų metų man sakys, būk malonus eik ị gatvę. Kur eiti? <..> Va taip va, čia tokia sistema, tokia įdomi, o pagal dokumentaciją vieną kartą čia gali gyventi per gyvenimą, pusantrų metų tau duoda, susirask, kur nori, ieškokis, ieškokis. Gerai, ieškokis... Jeigu aš turẻsiu pinigų, aš neisiu ir negyvensiu čia, teisingai? Tame dalykas, aš neisiu ir negyvensiu čia šitam Bangladeše... Pilna ta žodžio prasme galima taip pavadinti... čia dar baisiau... [Robertas, 57].

Remiantis LR socialinès apsaugos ir darbo ministro įsakymo „Dèl Socialinių paslaugų katalogo patvirtinimo“" (2006) IV str. 14.4. punktu, laikino apnakvin- 
dinimo paslauga teikiama vieną kartą, bet ne ilgiau kaip 3 paras. Galima daryti prielaidą, kad toks reglamentavimas, kai kalbama apie benamystę išgyvenančius žmones, netikslingas. Neretai laikino apnakvindinimo paslaugomis naudojasi tie asmenys, kurie neturi lèšų (,Jeigu aš turèsiu pinigų, aš neisiu ir negyvensiu čia, teisingai?") naudotis laikino apgyvendinimo paslaugomis ar išsinuomoti būstą. Praktiškai šiems asmenims sudaroma galimybẻ laikino apnakvindinimo paslauga naudotis ilgesnį laiką humaniškumo sumetimais, tačiau teisiškai tai yra vienkartinė paslauga, trunkanti ne ilgiau kaip tris paras. Toks reglamentavimas netikslus ir neorientuotas ị benamių žmonių poreikius. Roberto pasakojime ịdomu pastebèti tai, kad gyvenimas nakvynès namuose konstruojamas kaip gyvenimas „Bangladeše“. Galima daryti prielaidą, kad tokị vyro palyginimą su Bangladešo valstybe lemia nuolat jaučiamas skurdas, netvarka, kai kurių asmenų savęs nepriežiūra, gyvenimas kambariuose po kelis asmenis.

Tuo tarpu remiantis LR socialinès apsaugos ir darbo ministro įsakymo „Dèl LR socialinès apsaugos ir darbo ministro $2006 \mathrm{~m}$. balandžio 5 d. įsakymo Nr. A1-93 „Dèl socialinių paslaugų katalogo patvirtinimo“" pakeitimo“ (2013) 21.1 punktu, laikino gyvenimo namai apibrèžiami kaip socialinių paslaugų ịstaigos, teikiančios socialinę priežiūrą gyvenamosios vietos neturintiems ar laikinai negalintiems ja pasinaudoti asmenims bei trumpalaikę socialinę globą asmenims, kurie yra po medicininès reabilitacijos. Šių paslaugų trukmè - iki 6 mėnesių (IV str. 17 punktas). Be abejonès, benamystès problemą išspręsti pagal Socialinių paslaugų kataloge reglamentuotą tvarką tikrai sunku. Benamystė yra kompleksinis reiškinys, susijęs ne tik su būsto neturejimu, bet ir bedarbyste, vis ilgèjančiu senyvu amžiumi, socialinių paslaugų ir socialinio būsto neprieinamumu, priklausomybès ligomis. Tad žmogų apgyvendinus 3 paroms ar 6 mẻnesiams (,vieną kartą čia gali gyventi per gyvenimą, pusantrų metų tau duoda, susirask, kur nori“'), problema neišsispręs, ir jis vèl atsidurs gatveje, grị̌s prie senų ịpročių. Todèl labai svarbu išskirti benamių asmenų grupę, neprilyginant jų socialinès rizikos asmenims, nes išgyventi šị procesą reikia daugiau laiko, tuo labiau, kai kalbama apie vyresnio amžiaus asmenis.

Lejjus benamystės išgyvenimą sieja su tam tikromis socialinėmis paslaugomis: Išgyventi. Išgyventi, ir viskas.... < ..> kad turèti kur prisiglausti, kad gatvèje nebūti, kažkur po medžiais nemiegoti $\langle\ldots>$, jei būčiau invalidas baisiausias, gal kas nors išeitų, o aš dabar neturiu invalidumo. Buvo vienas be kojos, ịtaisè mūsų socialinès darbuotojos ị kartų namus, dabar iki galo savo gyvenimo pragyvens. O ką sveikų... ten irgi didžiausia eilè kartų namuose. Čia irgi kitas ị senelių namus, nu, tai senas labai, 80 metų su virš, dar vienas yra irgi ruošia jam popierius, 82 metų. $<\ldots>$ Sako, irgi sunku papulti [Lèjus, 72].

Lèjaus istorija atskleidžia, kad pagrindinis benamystės siekis ir tikejjimas susijęs su išgyvenimu gaunant tam tikras socialines paslaugas. Tačiau tyrimo dalyvio 
patirtis atskleidžia, kad Lietuvoje egzistuoja nemažai problemų socialinių paslaugu prieinamumo klausimu. Galima daryti prielaidą, kad ribotos galimybės gauti vieną ar kitą paslaugą skatina tyrimo dalyvio nepasitenkinimą ir prasmės gyvenime nebuvimą: „Čia nieko neišeis, pastangos tik tai bus, nieko neišreikalausi, dabar ta valstybè tokia... vaikštai, pats viską darai, neišeina kitaip.“

Nemažai spragų galima įžvelgti Lietuvos socialinio būsto politikoje. Socialinio būsto prieinamumas ir paskirstymas yra viena aktualesnių problemų: „Klausiau, pasakè skaičių virš 500, čia ant dešimt metų." Remiantis LR statistikos departamento duomenimis (2013), $2013 \mathrm{~m}$. buvo 32542 asmenys (šeimos), turintys teisę i socialinị būstą ir ịtraukti ị savivaldybėse sudaromus sąrašus. Akivaizdu, kad būsto laukti reiketų daugelį metų. Ilgą laukimo periodą patvirtina Erlando patirtis: „Koks čia tas greitai, 10 metų jau. Eilejje 10 metu.. Svarbu pastebėti, kad Erlandas yra darbingo amžiaus asmuo, jis gali užsidirbti pinigų ir susirasti pastogę, tuo tarpu benamiai žmonès, sulaukę pensinio amžiaus, neturi galimybių tiek metų laukti eilèje. Jiems būsto reikia čia ir dabar. Kita vertus, jeigu šią problemą išspręsti sudètinga, turètų būti sudarytos sąlygos šiems asmenims apsigyventi savarankiško gyvenimo namuose ar senelių globos namuose, bet ir čia kyla tam tikrų sunkumų: šių žmonių patalpinti neįmanoma dèl per didelių eilių. Taigi žmogus paliekamas likimo valiai: neturi nei būsto, nei minimalių finansinių išteklių:

Dabar dar pensijos negaunu, dar nesiunčia, reikia iš Rusijos, iš archyvų gauti, nes man nenori 10 metų priskaičiuoti prie pensijos. Dabar, kai Sodroje paskaičiavo stažą, tai 25 metų, o reikia, kad būtų 30, tai bus 35. Tai bus pensija, 240 eurų. $<\ldots>$ gaunu 94 eurus, kad, va, laukiu tos pensijos [Lejjus, 72].

Šiuo atveju labai svarbu kalbèti apie socialinị teisingumą. Tyrimo dalyvio naratyvas atskleidžia, kad Lietuvoje šis principas menkai igyvendinamas. Vienas pagrindinių socialinio teisingumo kriterijų yra visuomenès narių solidarumo principas, kuriuo remiantis siekiama ịgyvendinti tam tikrą lygybę minimaliai tenkinant būtiniausius poreikius. Lietuvoje ịvairiose srityse dominuoja turtas ir valdžia, kuri pasiskirstė nepagrịstai ir atsitiktinai. Didesnị turtą turinčios gyventojų grupės užsitikrina didesnị vartojimą ir socialinę apsaugą (Guogis, Gruževskis, 2010). Tai patvirtina ir tyrimo dalyvio patirtis: „I tuos senelių namus irgi nelabai nori priimti, turèk kažką, jei turi gerą pensiją, tai gal.“ Pasak A. Guogio (2006), neverta paminti žmoniškumo ir marginalizuoti didžiosios Lietuvos gyventojų dalies, nes čia ir taip daugumą sudaro marginalai, egzistuoja tik formali demokratija. Socialinio teisingumo nebuvimą atskleidžia ir Ąžuolo naratyvas:

Dantis tvarkau, nežinau, iš kur pinigų reikia gauti, neturiu ką pakišti jo, gali padaryti blogai, vèl reikès ne iš naujo, o laiko nebẻra, aš žmogus gi, jei mano gyvenimo ciklas būtų dar kokie 50 metų, jo, sutinku. O pagal visą mano būklę, man liko pagyventi, normaliai pagyventi kokia 15 metų, dar jaučiant savyje fizinę galią, jaunatvę, o 
toliau vsio, aš nežinau, kas bus, man neįdomu. Tai va, 15 metų, tą 15 metų, aš 5 metus dar susiplanavęs dar galiu įdèti ị save. Investuoti ị save, toliau jau viskas, pas mane jau irgi baigiasi ir kantrybė ir nervai, ne geležinis, dar tiek galiu, bet, jei viskas diena iš dienos, ką bedarytum, baigiasi blogais rezultatais, tai nedadeda jẻgų, nedadeda energijos, dar labiau smukdo [Ąžuolas, 50].

Azžuolo patirtis patvirtina tai, kad visuomenëje nusistovėjęs tam tikras galios santykis, kai finansų turejjimas lemia paslaugos kokybę („,nežinau, iš kur pinigų reikia gauti, neturiu, ką pakišti, jo, gali padaryti blogai"“). Tokiu atveju ypač svarbu keisti ir tobulinti socialinès apsaugos sistemos tikslus. Kaip teigia A. Guogis, B. Gruževskis (2010), svarbu užtikrinti visavertę piliečių socialinę integraciją ir dalyvavimą visuomeniniame gyvenime. Socialinès apsaugos pagrindą turètų sudaryti ne materialinis vartojimas, bet dalyvavimas. Kitaip tariant, nepaisant žmogaus finansinès padèties, gyvenamosios vietos, jam svarbu užtikrinti galimybę dalyvauti ekonominiame, politiniame, pilietiniame ir kultūriniame valstybès gyvenime. Socialinès apsaugos efektyvumą turi atskleisti ne pajamos ar finansinè galia, bet socialinès rizikos asmenų dalyvavimas visuomeniniame gyvenime. Ąžuolo istorija patvirtina tai, kad dabartinè socialinès apsaugos sistema skatina asmenis jaustis bejègiais, pagalbos nesulaukiančiais asmenimis: „Bet jei viskas diena iš dienos, ką bedarytum, baigiasi blogais rezultatais, tai nedadeda jègų, nedadeda energijos, dar labiau smukdo." Valstybès vaidmuo tyrimo dalyvio apibūdinamas taip:

Iš tikro, iš tikro, pačios valstybès pasigendu, pasigendu, pačios valstybès pagarbos, dèmesio, visur absoliučiai, nesvarbu, ar tai būtų mokama, ar tai būtų nemokama, nebèra to, kas buvo kažkada. Už pinigus gali visa tai nusipirkti, ir kokybę nusipirkti gali, ir nusipirkti dirbtinę šypseną, tą tokị pagarbų elgesị, bet tik už pinigus, o be pinigų, vsio [Ažzuolas, 50].

Galima daryti prielaidą, kad nesiekiant pokyčių ir efektyvesnių bei prieinamesnių socialinių paslaugų, Lietuvoje vis dėlto gali padaugėti nusikalstamos veikos: „Todèl, kad aš laisvas žmogus, galiu eiti plèšti, galiu eiti atimti, bet kažkodèl myliu žmones, žinai.“

Ir Tauro naratyvas atskleidžia vyro nusivylimą valstybès pagalba:

Valstybė tikrai nepadès. Jokių minčių nèra. Mes nepasieksime kitų šalių praktikos, pas mus kaip buvo, taip ir bus. Jūs kiek norite galite verstis per galvą, gerai, kad tokius namus padare , dar gerai. < ..> reikia keisti bet nieko neịmanoma $<\ldots>$ iš tikrujų, tarkim, gerai, 4 metai, 4 metai atgal, nakvynès namuose buvau laikino apgyvendinimo namuose nakvynès namuose, dirbau Joniškyje iš nevilties, mane apgavo. Ir aš išèjau ị nemokamus, mane pervedè, tai patalynė buvo, rankšluostis buvo. Dabar po 5 metų čia atėjau, vèl nuejjau ị nemokamus $<\ldots>$ Tai ten nueinu dabar... nu, aš utėlių bijau, aš trinuosi su tepalais, ten utėlynas, ten nieko nebėra, ten nebėra ị ką žiūrèti, miegok kiek 
nori, valgyk kiek nori, šilta, eik, išsimaudyk ir miegok. $<\ldots>\mathbf{O}$ ateity benamių dar daugiau atsiras. $\mathrm{O}$ vasarą, ką vasarą... kur miegoti? Ant suoliukų niekas neima, nei policija neima, niekas. Kam reikalingas? $<\ldots>$ Eik, susirk kokia džiova, ir viskas. Šito žmogaus niekur nepaguldo, jis be kojos, sėdi ant suoliuko, prašo... geria bet ką, viskas, kas dega, išskyrus malkas, ir jokio dėmesio... kokị dèmesį gali duoti? Pagalbą duoda, savaitę dvi ar mẻnesị pramiegojo prie stoties, davė jam pagalbą, padėdavo, davė protezą, įtaisė ir kas iš to, jis vèl miega lauke... [Tauras, 64].

Viena vertus, galima teigti, kad vyras nesistengia, nemotyvuotas (,nėra didelio noro keltis“) keisti tokio savo gyvenimo, kita vertus, galima akivaizdžiai pastebėti, kad benamystę išgyvenantiems asmenims teikiamos paslaugos turètų būti ne trumpalaikès, bet ilgalaikès. Pasak V. Bush-Geertsema, O’Sullivan, Pleace (2010), dalis benamių išgyvena ilgalaikę benamystę, tokiu atveju ypač svarbi kuo didesnè parama. Tradiciškai benamiams suteikiamos institucinės paslaugos, kurios ne visada būna sėkmingos ar efektyvios. Viešoje erdvèje svarstoma, kad ūmios benamystès atveju tikslinga būtų suteikti nuolatinę gyvenamąą vietą, socialinį būstą, o ne laikiną pastogę, vadovaujantis principu - „,būsto pirmumas“ (angl. Housing First model). Tačiau tokio principo užtikrinimas labai priklauso nuo socialinio būsto prieinamumo, socialinės apsaugos sistemos funkcionavimo, tinkamos krizių intervencijos ir lanksčių bei prieinamų socialinių paslaugų. Lietuvoje vis dèlto socialinio būsto srityje ne vienas tyrimo dalyvis įžvelgia prieinamumo problemą:

Tyrèja: o kaip dèl socialinio būsto? Jūs nestovite eilèje?

Tauras: ne. Nėra šansų. Nedagyvensiu, kol gausiu tą būstą. I nakvynès namus, va, visi gali eiti.

Tyrimas atskleidžia, kad benamiams asmenims dẻl socialinių paslaugų neprieinamumo atsiranda galimybe tapti ilgalaikiais benamiais. Atsižvelgę i tai, mokslininkai L. Gulcar, A. Stefancic, M. Shinn, S. Tsemberis, S. Fischer (2003) skiria du darbo su ilgalaikiais benamiais modelius. Būsto pirmumo modelis (angl. Housing first model) apibrèžiamas kaip nuolatinio būsto suteikimas su palaikomaja socialine pagalba (sveikatos priežiūra, socialinis darbas su atvejais ir kt.) motyvuotiems asmenims, kurie gali turéti negalią, psichikos sutrikimų. Antrasis modelis - tiesioginis, suprantamas kaip nakvynės namų paslauga, kurioje teikiamos nuolatinės socialinès paslaugos asmenims, praradusiems viltị ir motyvaciją. Socialinių paslaugų srityje Vakaris ir Robertas taip pat ị̌̌velgia trūkumą:

$\mathrm{Nu}$, viena naktis... jie neleidžia... Bet aš ten nakvoju velnias žino kiek. Aš ne vietinis.

Priregistruotas kitur. <..> Va, čia aš nesuprantu, humaniškumo jokio nėra. Žmogus šalk, šlapk. Pernakvoti, cha cha... nevietinis. Tai kaip ne vietinis? Aš lietuvis! Aš čia gimiau, dar ko. Kaip tai aš ne vietinis, koks čia skirtumas gali būti? Čia yra nesąmonè. 
Koks čia skirtumas? Jeigu ligoninės priima ị koridorius benamius, o čia jie turi vietos, turi visko ir nepriima... savo žmonių... [Vakaris, 50].

Žmogus neturi, kur gyventi, neturi nei pajamų, nei nieko, kas, jei turi, čia ateina gyventi... bet jeigu jis neturi nei paso, nieko, jis ten papuolè, kur jam ten eiti tam žmogui? Jūs suprantat, tokių variantų, jūs suprantat, aišku... aš žinau, suprantat, protingas žmogus, kiekvienas supranta, jis padèti nieko negali... [Robertas, 57].

Galima daryti prielaidą, kad gyvenimas rajonuose ar miestuose, kuriuose asmuo priregistruotas, bet nėra nakvynès namų, iš tiesų sukelia problemų. Iš esmès žmogus, siekdamas susirasti darbą, apsisaugoti nuo aplinkos (pvz., esant benamiu sutikti pažístamų žmonių), gali išvykti ị kitą miestą ir jame likti, tačiau tai reiškia, kad jis nèra tos savivaldybės gyventojas ir jam socialinès paslaugos nepriklauso. Be abejonès, teisiškai socialinès paslaugos negali būti teikiamos asmenims, nedeklaravusiems gyvenamosios vietos tame mieste, kur jie siekia gauti tam tikras socialines paslaugas: „Dėl socialinių paslaugų, kurių teikimą finansuoja savivaldybė iš savo biudžeto lèšu ar iš valstybès biudžeto lěšų specialiųų tikslinių dotacijų savivaldybių biudžetams, skyrimo asmuo (vienas iš suaugusių šeimos narių) ar jo globèjas, rūpintojas raštišku prašymu kreipiasi ị asmens (šeimos) gyvenamosios vietos savivaldybę“" (LR Socialinių paslaugų įstatymas, 2006). Tačiau žvelgiant iš socialinio darbo perspektyvos, benamystę išgyvenantys asmenys turètų gauti bent minimalias socialines paslaugas iš tos savivaldybès, kurioje jie tuo metu yra (ne visada benamystę išgyvenantis asmuo turi galimybę grịžti ị tą miestą, rajoną, iš kurio atvyko).

Lukas benamystę išgyvena jau 9 metus. Pasak M. Crane, M. A. Warnes (2007), dauguma senyvo amžiaus benamių susiduria su įvairialypėmis ir giliai įsišaknijusiomis problemomis (psichikos sutrikimai, fizinès sveikatos problemos, aktyvumo sumažejjimas), o dabartinès nakvynès namų paslaugos nepakankamai pritaikytos senyvo amžiaus benamiams: jiems kyla didesnè rizika patirti smurtą iš jaunesnių žmonių, jie yra jautresni keliamam triukšmui. Luko patirtis byloja ir tai, kad jis siekia ramybės (,kad būtų ramybéc). Viena vertus, jis ją stengiasi palaikyti gyvendamas tam tikru režimu, kita vertus, siekdamas labiau susibendrauti su moterimi, su kuria ramiai norètų nugyventi likusi gyvenimą (,man meilès tikrai reikia“; „Marija, tave čia pasitiksiu, važiuosim pas tave gyventi“‘). Nakvynės namų paslaugos ir kitos socialinès paslaugos nepritaikytos ir neprieinamos senyviems asmenims, turintiems judejjimo negalią:

Savarankiški namai, va, aš čia nesiruošiu, skambinau savo draugui, ruošk vietą. Savarankiško gyvenimo namuose, va, ir nuvažiavimas yra. Nuo laiptų man nereikia prašyti, arba, kas nuneš, ar dar ką. Ten nuvažiavimas, aš pats gaminu, galiu pasigaminti už savo pinigus. < ..> Vaikščiosiu su lazdom, mesiu tą vaikštynę [Lukas, 71]. 
Tyrimo dalyvio istorijoje galima pastebèti, kad vis dèlto nakvynès namų patalpos nepritaikytos asmenims, turintiems judèjimo negalią. İstaigos nepajėgios pačios išspręsti šių problemų dèl tam tikrų objektyvių priežasčiu (finansavimo nebuvimo). Todèl ypač svarbu imtis veiksmų politiniu lygmeniu, inicijuojant tam tikrus pokyčius šioje srityje. Pasak M. Crane, M. A. Warnes (2007), ypač svarbu plètoti paslaugas senyvo amžiaus benamiams asmenims: Amerikoje ịsteigti namai, skirti specialiai šiems žmonėms. Šiuose namuose teikiamos sveikatos, socialinès priežiūros ir apgyvendinimo paslaugos. Bostone ir New Yorke kiekvienam minètam asmeniui suteikiamas vienvietis kambarys su virtuve ir vonia. Socialinių paslaugų plètra senyvo amžiaus žmonėms ypač svarbi, viena vertus, dèl to, kad vis daugėja šio amžiaus žmonių: „Gana gausi yra vyresnio amžiaus benamių grupe““(Kanopienè, Mikulioniené, 2004). Kita vertus, jiems vis sudètingiau pasirūpinti savimi ir siekti savo išgyvenimo nesant jiems būtinų ir pritaikytų socialinių paslaugų.

Apibendrinant reikia pastebėti, kad Lietuvoje egzistuoja nemažai problemų socialinių paslaugų prieinamumo klausimu. Lietuvoje socialinès apsaugos sistemos pagrindą sudaro materialinis vartojimas, bet ne socialinès rizikos asmenų dalyvavimas visuomeniniame gyvenime, dèl ko menkai igyvendinamas socialinio teisingumo principas. Tyrimo metu pastebèta, kad judejimo negalią turintiems asmenims X nakvynès namų infrastruktūra nepritaikyta, nors asmenų, turinčių vienokią ar kitokią negalią, skaičius yra nemažas. Tyrimas taip pat atskleidè, kad socialinès paslaugos turètų būti ne trumpalaikès, bet ilgalaikès, orientuotos ị senyvo amžiaus benamių asmenų poreikius. Viena vertus, dẻl to, kad šios amžiaus grupès asmenų daugẻja, kita vertus, jiems vis sudètingiau pasirūpinti savimi ir išgyventi.

\section{Išvados}

1. LR teisès aktai reglamentuoja, kad benamystę išgyvenantys asmenys turi teisę gauti tam tikras socialines paslaugas, kurios teikiamos socialinių paslaugų ịstaigose, arba turi galimybę pretenduoti ị socialinio būsto ịsigijimą. Analizuojant ịvairius dokumentus, reglamentuojančius socialinių paslaugų teikimą, pastebèta, kad jos yra trumpalaikès, nors ir orientuotos ị socialinès atskirties ịveiką. Daroma teorinè prielaida, kad nesant ilgalaikès pagalbos, benamystę išgyvenantys žmonès, pasinaudoję jiems skirtomis paslaugomis, vèl atsiduria gatveje, todèl stengiasi išgyventi vartodami psichotropines medžiagas, atlikdami nusikalstamą veiką ir kt.

2. Socialinio būsto teikimas mokslineje ir teisineje literatūroje siejamas su solidarumo principu, kuris išryškina valstybės teikiamos pagalbos svarbą vargingiau gyvenančiai visuomenès daliai. Tuo tarpu statistiniai rodikliai 
atskleidžia kitą pusę: socialinio būsto poreikis šalyje smarkiai auga, o eilèse žmonès priversti laukti 10 ir daugiau metų, todèl daroma prielaida, kad valstybè nelabai pajègi suteikti pagalbą skurdžiau gyvenantiems asmenims.

3. Tyrimo rezultatai patvirtino egzistuojančią praktiką, kad Lietuvos socialinès apsaugos sistema paremta materialiniu aprūpinimu, tad benamių vyrų galimybės gauti kokybišką paslaugą yra menkos. Todẻl benamystė Lietuvoje trunka didžiają žmogaus gyvenimo dalị, kai ne tik pažeidžiamas žmogaus orumas ir teisès, bet ir nepatenkinami minimalūs jo poreikiai. Tyrimas atskleidè, kad judejjimo negalią turinčiam žmogui nakvynès namų infrastruktūra nepritaikyta; socialinis būstas dẻl ilgų eilių sunkiai gaunamas, o benamystę išgyvenantys asmenys negali eilèse laukti 10 ir daugiau metų, neturėdami kur gyventi. Jiems socialinès pagalbos reikia čia ir dabar. Tol, kol nebus ilgalaikių socialinių paslaugų arba jos netaps labiau prieinamos, žmonių, gyvenančių gatvèse, skaičius nemažès.

4. Tyrimas atskleide, kad savarankiško gyvenimo ar senelių globos namai garbaus amžiaus benamiams taip pat sunkiai prieinami. Benamių vyrų patirtis leidžia kalbèti apie tai, kad socialinès paslaugos turi būti ne trumpalaikès, o ilgalaikès, ypač, kai kalbama apie senyvo amžiaus asmenis. Svarbu pastebèti, kad benamystès reiškinị išgyvena vis didesnis skaičius pensinio amžiaus žmonių, o socialinès paslaugos neatitinka šių asmenų poreikių, todèl neužtikrinamas žmogaus orumas. Tyrimo dalyviai nesitiki pagalbos iš valstybès, bet turi vilties gauti kokybiškesnes, labiau prieinamas socialines paslaugas.

Gauta 20170203

Pasirašyta spaudai 20170522

\section{Literatūra}

Biudžetinès isstaigos Vilniaus miesto socialinès paramos centro $2014 \mathrm{~m}$. veiklos ataskaita. (2015). Prieiga internete: http://www.spcentras.lt/page/upload/Veiklos_ataskaita_2015.pdf [žiūrèta 2017-04-22].

Bush-Geertsema, V., O’Sullivan, Eoin, E.W., Pleace, N. (2010). Homelessness and Homeless Policies in Europe: Lessons from Research. European Consensus Conference on Homelessness. Prieiga per internetą: http:// www.sociallabel.be/sites/default/files/doc/116829_pod_broch_homelessnes_eng_v3_0.pdf

Crane, M., Warnes, M. A. (2007). Responding to the needs of older homeless people. Innovation: The European Journal of Social Science Research, Vol. 18(2), p. 137-152.

Cronley, C. (2010). Unraveling the Social Construction of Homelessness. Journal of Human Behavior in the Social Environment, Vol 20, p. 319-330.

Dromantienè, L. (2008). Socialinès Europos kūrimas. Vilnius: Mykolo Romerio universiteto Leidybos centras.

Europos socialinè chartija. (2001). Valstybès žinios, Nr. 49-1704. Prieiga internete: http://www3.lrs.lt/pls/inter3/ oldsearch.preps2?Condition $1=42260 \&$ Condition2 $=$ [žiūrèta 2015-03-09]. 
FEANTSA. Panaikinti benamyste yra įmanoma! Prieiga internete: http://www.feantsa.org/spip.php?action= acceder_document\&arg=561\&cle $=$ f9 1 db52718ce 5 b $9 \mathrm{cc} 5184 \mathrm{f} 757 \mathrm{c} 251 \mathrm{c} 6225 \mathrm{c} 18 \mathrm{adb} \& \mathrm{file}=\mathrm{pdf} \% 2 \mathrm{Ff}$ ea_001-09_lt.pdf [žiūrèta 2017-04-22].

Gulcar, L., Stefanic, A., Shinn, M., Tsembris, S., Fischer, S. (2003). Housing, hospitalization, and cost outcomes for homeless individuals with psychiatric disabilities participating in continuum of care and housing first programmes. Journal of Community \& Applied Social Psychology, Vol. 13(2), p. 171-186.

Guogis, A. (2006). Kai kurie korporatyvinès socialinès atsakomybès ir socialinio teisingumo aspektai. Viešoji politika ir administravimas, Nr. 18, p. 73-77.

Guogis, A., Gruževskis, B. (2010). Ar reikia kitokio Lietuvos visuomenès socialinès raidos modelio? Socialiniu mokslu studijos, Nr. 3(7), p. 19-35.

Joint Memorandum on Social Inclusion of Lithuania. (2003). Brussels. Prieiga internete: http://www.socmin.lt/lt/ veikla/koncepcijos-strategijos.html [žiūrèta 2017-04-22]

Kanopienė, V., Mikulionienė, S. (2004). Lietuvos benamiai: gyvenimo sąlygos. Socialinis darbas, Nr. 3(1), p. $47-62$.

Lietuvos Respublikos 2004-2006 metu nacionalinis kovos su skurdu ir socialine atskirtimi veiksmu planas. Prieiga internete: http://www.socmin.lt/lt/veikla/koncepcijos-strategijos.html [žiūrèta 2017-14-22].

Lietuvos Respublikos socialinès apsaugos ir darbo ministro isakymas „Dèl Lietuvos Respublikos socialinès apsaugos ir darbo ministro 2006 m. balandžio 5 d. isakymo Nr. A1-93 „Dél socialiniu paslaugu katalogo patvirtinimo " pakeitimo“. (2013). Nr. A1-368. Prieiga internete: http://www3.lrs.lt/pls/inter3/dokpaieska. showdoc_1?p_id=453424 [žiūrèta 2017-04-22].

Lietuvos Respublikos Socialiniu paslaugu istatymas. (2006). Nr. 17-589. Prieiga internete: http://www3.lrs.lt/pls/ inter2/dokpaieska.showdoc_1?p_id=478938 [žiūrèta 2017-04-22].

Lietuvos statistikos departamentas. Asmenys (šeimos), buvę sąrašuose socialiniam būstui nuomoti. Prieiga internete: http://db1.stat.gov.lt/statbank/selectvarval/saveselections.asp?MainTable=M3100201\&PLang uage $=0$ \& TableStyle $=\&$ Buttons $=\&$ PXSId $=2721 \& \mathrm{IQY}=\& \mathrm{TC}=\& \mathrm{ST}=\mathrm{ST} \& \mathrm{rvar} 0=\& \mathrm{rvar} 1=\& \mathrm{rvar} 2=\& \mathrm{rvar}$ 3=\&rvar4=\&rvar5=\&rvar6=\&rvar7=\&rvar8=\&rvar9=\&rvar10=\&rvar11=\&rvar12=\&rvar13=\&rvar14= [žiūrèta 2017-04-22].

LR Socialinès apsaugos ir darbo ministerija. Socialinès ịtraukties didinimo 2014-2020 m. veiksmu planas. 2013 m. spalio 22 d. Nr. A1-588. Prieiga internete: http://www.socmin.lt/download/6579/socialines $\% 20$ itraukties\%20veiksmu-planas.pdf [žiūrèta 2017-04-22].

LR Valstybès paramos būstui ịsigyti ar išsinuomoti ịstatymas. (2014). Teisès aktų registras, Nr. 2014-15180. Prieiga internete: http://www3.lrs.lt/pls/inter3/dokpaieska.showdoc_1?p_id=478801 [žiūrèta 2017-04-22].

Praspaliauskienè, R. (2000). Nereikalingi ir pavojingi: XVIII a. pabaigos ir XIX a. pirmosios pusés elgetos, valkatos ir plèšikai Lietuvoje. Žara.

Skurdo mažinimo Lietuvoje strategija. (2000). Vilnius. Prieiga internete: http://www.socmin.lt/lt/veikla/ koncepcijos-strategijos.html [žiūrèta 2017-04-22].

Tainio, H., Fredriksson, P. (2009). The Finnish Homelessness Strategy: From a 'Staircase' Model to a 'Housing First' Approach to Tackling Long-Term Homelessness. European Journal of Homelessness, Vol. 3, p. 181199.

Vilniaus miesto savivaldybės tarybos sprendimas. (2013). Socialinès rizikos asmenu, neturinčiu nuolatinès gyvenamosios vietos, ir elgetaujančiujų 2013-2018 metu integracijos ir socialinès pagalbos programa. Vilnius. 


\title{
IMPLEMENTATION OF LITHUANIAN SOCIAL SERVICES FOR THE HOMELESS: THE EXPERIENCES OF HOMELESS MEN
}

\author{
Violeta Ivanauskienė, Natalja Gončiarova
}

\section{Summary}

Homelessness has existed in all historical times. The problem of homelessness is the object of the interdisciplinary study, which cannot squeeze in sociology, criminology and ethnology frames (Praspaliauskienè, 2000). With reference to critical approach homelessness is the consequence of the individual and structural factors. Homelessness can lead to personal problems, addiction diseases or poor living conditions, which associates with a wide range of systematic factors such as inaccessibility of housing and lack of employment opportunities (Kuhn, Culhane, 1998) (cited by Cronley, 2010). Homeless people face with of social and economic resources. The state must ensure the rights of persons, who are suffering homelessness and preserve their dignity. Meanwhile, the regulation and implementation of social services for homelessness allows to talk about the development of the modern state, when shaping and reshaping the model of social services. Vei-Wilson (2000) (cited by Dromantienè, 2004) analyzed the concept of the welfare state and claimed that its essence is the state's ability to reduce poverty, social exclusion and protect human rights. Esping-Andersen (1990) (cited by Dromantienè, 2004) argues that the welfare state is associated with the state's liability for certain minimum welfare grant to their citizens. In order to eradicate poverty, social exclusion, to assure equality in welfare state, it is important to talk and explore the regulation and implementation of state's social services not only on the basis of the academic literature, but also on the experience of service users'. Therefore, this article explores the experiences of men who are suffering homelessness, trying to identify the main problems of social services and to show the potential of their development. The object of the research - the implementation of social services for homeless people in Lithuania.

The method of the research. The analysis of implementation of Lithuanian social services for homeless people from the point of view of homeless men's, is based on a qualitative study. 9 semi-structured qualitative interviews with men, who were living in the hostel for homeless people were performed. The average time of the interviews were 55 minutes. The participants were selected on the basis of the principle of a snowball, when the first participants were recommended by 
the hostel staff, and further study participants were recommended by the previous participants. The study was conducted according to ethical requirements for the research: confidentiality, anonymity, and impartiality. The research findings are presented in the authentic language of the research participants.

Theoretically, homeless people have the right to get some special social services, which are provided by social services offices and have the opportunity to apply for social housing acquisition. The analyses of some special documents, which regulate the provision of social services, have shown that the services are shortterm, and they are focused on the overcoming of social exclusion. In theoretical perspective, homeless people, who are not getting long-term services, become homeless people again. Social housing provision in the academic literature is related to the solidarity principle, which highlights the importance of state assistance to poor group of the population. Meanwhile, the statistical indicators reveal a slightly different issues: the need for social housing in the country is rising, and the people are forced to wait for more than 10 years. It is assumed that the state is not able to provide assistance for poor people. According to the results of the research, in the practical context, Lithuanian social security system is based on material provision, so the services homeless men can get are quite poor. Therefore, the situation of homelessness in Lithuania violates men's human rights and their dignity. The empirical data showed that the infrastructure of hostels is not available for persons with disabilities; social housing is hardly available because of long queues and homeless people cannot wait for 10 years or more without a place to live. Homeless men need the social assistance "now and here". The number of homeless people will not decrease until the long-term social services are provided or they will become more accessible to people living in the streets. The empirical data also revealed that the services of independent living or nursing home for elderly homeless men are also difficult to access. The practical experience of homeless people allows to speak about the fact that social services must not be short-term but long-term. 